\title{
A case series of dupilumab-treated atopic dermatitis resulting in new onset psoriasis
}

\begin{abstract}
Dupilumab is the first biologic agent approved for the treatment of moderate-to-severe atopic dermatitis (AD). Although throughout clinical testing the medication only caused minor side-effects, there have been an increasing amount of reports of new onset psoriasis during the course of treatment of AD with Dupilumab. This case series explores the previously reported cases of this novel side effect of Dupilumab and then reports the five novel cases that have been previously unrecorded. The findings support a previously proposed TH-1 overdrive based mechanism for the unusual psoriasis development and serve to urge physicians to monitor patients closely on Dupilmab for this potential side effect.
\end{abstract}

Volume 4 Issue 4 - 2020

\author{
Marta Turowski BS,' Lauren Boudreaux, ${ }^{2}$ \\ Rachel Klein, ${ }^{3}$ Karsten Johnson, ${ }^{2}$ Alison \\ Carrigg, ${ }^{2}$ Andrea Garrett, ${ }^{4}$ David High ${ }^{3}$ \\ 'University of Illinois at Chicago Chicago, USA \\ ${ }^{2}$ Silver Falls Dermatology Portland, USA \\ ${ }^{3}$ Accent Dermatology Medford, USA \\ ${ }^{4}$ Forefront Dermatology Ann Arbor, USA
}

Correspondence: Lauren Boudreaux, Silver Falls Dermatology, USA, Tel 503-362-8385, Email lboudreux@silverfallsderm.net

Received: July 06, 2020 | Published: August 21, 2020

\section{Introduction}

Psoriasis and Atopic Dermatitis (AD) share a common inflammatory-based mechanisms, but are rooted in unique branches of the cytokine pathway, with psoriasis being driven by Th- 1 and Th17 pathways and AD rooted in the Th-2 pathway. The two diseases also differ morphologically, typically allowing dermatologists to distinguish between the two conditions and appropriately tailor treatment.

Dupilumab is the first biologic agent approved for the treatment of adults with moderate-to-severe $\mathrm{AD}$, targeting the IL-4 receptor $\alpha$. Its efficacy and safety have been studied repeatedly and only minor side effects have been reported. ${ }^{1-4}$ As the use of dupilumab expands, there are more case reports suggesting unreported cutaneous side effects, such as new-onset psoriasiform dermatitis.

\section{Literature review}

Several cases describing the development of psoriasiform dermatitis during the use of dupilumab have been published. In the majority of cases, new lesions suspicious for psoriasis were confirmed by biopsy. Patients typically received the standard dosing of dupilumab, with sudden onset of psoriasiform dermatitis that was responsive to classic treatments for psoriasis (Table 1).

\section{Methods}

Upon discovery of a novel case of dupilumab-treated atopic dermatitis resulting in new onset psoriasis, a call for similar cases was conducted on an online national board-certified dermatologist group. Several physicians reported similar findings and submitted their patient's cases, with their consent, along with any relevant figures.

\section{Case presentations}

Five male patients age ranged from 30-69 were each diagnosed with moderate-to-severe AD. They were initially treated with traditional topical and systemic therapies for atopic dermatitis such as topical steroids, calcineurin inhibitors, and oral immune suppressants. Ultimately, all patients required dupilumab with improvement noted in their first few months of treatment. Psoriaform dermatitis presented at varying timelines. In $4 / 5$ cases, the diagnosis of presumed druginduced psoriasis was supported with biopsies and pathology consistent with the morphologic changes noted in clinic (Figure 1). In $4 / 5$ cases patients were able to fully recover from psoriaform plaques when dupilumab was discontinued. In some cases, patients were able to restart Dupilumab without reoccurrence of psoriaform findings. However, in one case, the rash persisted despite several treatment attempts. (Table 2).

\section{Discussion}

In this case series, we demonstrate a novel side-effect of dupilumab. The mechanism for drug-induced psoriasiform dermatitis has not been fully elucidated. We support the proposition that this is likely a shift from Th-2 to Th-1 based inflammation induced by dupilumab. It is postulated that by blocking Th-2, dupilumab causes the Th- 1 cascade to work in overdrive, eventually leading to Th-1 disease such as psoriasis. ${ }^{1,4,5}$ Studies have shown that IL-4 is a negative regulator of Th-1 and Th-17 cells, which can inhibit the formation of psoriatic lesions. As a result, there is further support that blocking Th-2 responses with dupilumab through IL-4/IL-13 could result in a shift to Th-1 and Th-17 based inflammatory cytokine cascades that lead to psoriasis. ${ }^{5}$ It is also postulated that select patients may be more susceptible to this side effect, as they inherently have overactive Th1 pathways. 
Table I Below is a chart summarizing the previously reported case studies

\begin{tabular}{|c|c|c|c|c|c|c|}
\hline $\begin{array}{l}\text { Patient } \\
\text { description }\end{array}$ & $\begin{array}{l}\text { Time treated } \\
\text { AD with } \\
\text { dupilumabprior to } \\
\text { symptoms }\end{array}$ & $\begin{array}{l}\text { Location of } \\
\text { psoriasiform } \\
\text { lesions }\end{array}$ & Biopsy results & $\begin{array}{l}\text { Subtype of } \\
\text { psoriasis } \\
\text { diagnosed }\end{array}$ & $\begin{array}{l}\text { Treatment } \\
\text { choice for } \\
\text { psoriform } \\
\text { lesions when } \\
\text { occurred }\end{array}$ & Citation \\
\hline $\begin{array}{l}50 \text { year old } \\
\text { female with } \\
A D \text { and } \\
\text { asthma }\end{array}$ & 4 months & $\begin{array}{l}\text { Bilateral upper } \\
\text { and lower } \\
\text { extremities, } \\
\text { trunk }\end{array}$ & $\begin{array}{l}\text { Arm: Psoriasiform } \\
\text { hyperplasia with } \\
\text { a diminished } \\
\text { granular layer and } \\
\text { focal collections of } \\
\text { neutrophils within } \\
\text { parakeratotic scale. } \\
\text { There was a brisk } \\
\text { perivascular and } \\
\text { diffuse dermal } \\
\text { infiltrate of } \\
\text { neutrophils with } \\
\text { admixed histiocytes } \\
\text { and occasional } \\
\text { eosinophils } \\
\text { Abdomen: Irregular } \\
\text { acanthosis, mild } \\
\text { spongiosis, and } \\
\text { intraepidermal } \\
\text { neutrophils forming } \\
\text { subcorneal pustules. } \\
\text { The granular layer was } \\
\text { maintained with focal } \\
\text { parakeratosis }\end{array}$ & $\begin{array}{l}\text { Erythrodermic } \\
\text { psoriasis }\end{array}$ & $\begin{array}{l}\text { Methotrexate and } \\
\text { topical steroids }\end{array}$ & 3 \\
\hline $\begin{array}{l}40 \text { year old } \\
\text { female with } \\
A D\end{array}$ & 16 weeks & $\begin{array}{l}\text { Trunk and } \\
\text { extremities }\end{array}$ & $\begin{array}{l}\text { Parakeratosis, } \\
\text { hyperkeratosis, } \\
\text { acanthosis, dilated } \\
\text { capillaries, and a } \\
\text { lymphocytic infiltrate } \\
\text { in the upper dermis }\end{array}$ & $\begin{array}{l}\text { Guttate } \\
\text { psoriasis }\end{array}$ & $\begin{array}{l}\text { Continued } \\
\text { duplimab and } \\
\text { added daily topical } \\
\text { calcipotriol- } \\
\text { betamethasone } \\
\text { foam }\end{array}$ & 2 \\
\hline $\begin{array}{l}55 \text { year old } \\
\text { male with } A D\end{array}$ & 2 months & Trunk & $\begin{array}{l}\text { Parakeratosis, } \\
\text { hyperkeratosis, } \\
\text { acanthosis, dilated } \\
\text { capillaries and a } \\
\text { lymphocytic infiltrate } \\
\text { in the upper dermis }\end{array}$ & $\begin{array}{l}\text { Psoriasis } \\
\text { Vulgaris }\end{array}$ & $\begin{array}{l}\text { Continued } \\
\text { dupilumab and } \\
\text { added topical } \\
\text { steroid }\end{array}$ & 3 \\
\hline $\begin{array}{l}59 \text { year old } \\
\text { female with } \\
\text { AD }\end{array}$ & $\begin{array}{l}4 \text { weeks (second } \\
\text { round of } \\
\text { treatment, was } \\
\text { first discontinued } \\
\text { by patient after } 36 \\
\text { weeks) }\end{array}$ & $\begin{array}{l}\text { Upper } \\
\text { and lower } \\
\text { extremities }\end{array}$ & $\begin{array}{l}\text { Confluent } \\
\text { parakeratosis with } \\
\text { absent granular } \\
\text { cell layer, regular } \\
\text { acanthosis, and } \\
\text { thinning of the } \\
\text { suprapapillary plates }\end{array}$ & $\begin{array}{l}\text { Psoriasis } \\
\text { Vulgaris }\end{array}$ & $\begin{array}{l}\text { Discontinued } \\
\text { dupilumab } \\
\text { and added } \\
\text { triamcinolone } \\
\text { ointment }\end{array}$ & 4 \\
\hline $\begin{array}{l}54 \text { year old } \\
\text { male with } A D\end{array}$ & 8 months & $\begin{array}{l}\text { Bilateral upper } \\
\text { and lower } \\
\text { extremities, } \\
\text { chest, back, neck, } \\
\text { and abdomen }\end{array}$ & $\begin{array}{l}\text { Acute spongiotic } \\
\text { dermatitis with } \\
\text { lymphocyte exocytosis }\end{array}$ & $\begin{array}{l}\text { Palmoplantar } \\
\text { and } \\
\text { erythrodermic } \\
\text { psoriasis }\end{array}$ & $\begin{array}{l}\text { Discontinued } \\
\text { dupilumab }\end{array}$ & $\mathrm{I}$ \\
\hline $\begin{array}{l}49 \text { year old } \\
\text { female with } \\
A D\end{array}$ & 1.5 years & $\begin{array}{l}\text { upper and lower } \\
\text { extremities }\end{array}$ & $\begin{array}{l}\text { Scattered, disorganized } \\
\text { fingernail pits }\end{array}$ & None reported & $\begin{array}{l}\text { Continued } \\
\text { dupilumab and } \\
\text { added twice- } \\
\text { daily clobetasol } \\
\text { ointment }\end{array}$ & 1 \\
\hline
\end{tabular}


Table Continued...

\begin{tabular}{|c|c|c|c|c|c|c|}
\hline $\begin{array}{l}\text { Patient } \\
\text { description }\end{array}$ & $\begin{array}{l}\text { Time treated } \\
\text { AD with } \\
\text { dupilumabprior to } \\
\text { symptoms }\end{array}$ & $\begin{array}{l}\text { Location of } \\
\text { psoriasiform } \\
\text { lesions }\end{array}$ & Biopsy results & $\begin{array}{l}\text { Subtype of } \\
\text { psoriasis } \\
\text { diagnosed }\end{array}$ & $\begin{array}{l}\text { Treatment } \\
\text { choice for } \\
\text { psoriform } \\
\text { lesions when } \\
\text { occurred }\end{array}$ & Citation \\
\hline $\begin{array}{l}\text { Female in } 50 \text { s } \\
\text { with asthma } \\
\text { and } A D\end{array}$ & 2 months & $\begin{array}{l}\text { Widespread: } \\
\text { scalp, trunk } \\
\text { and bilateral } \\
\text { upper and lower } \\
\text { extremities with } \\
\text { thick white scale }\end{array}$ & $\begin{array}{l}\text { Psoriasiform } \\
\text { hyperplasia with } \\
\text { a diminished } \\
\text { granular layer and } \\
\text { focal collections of } \\
\text { neutrophils within } \\
\text { parakeratotic scale }\end{array}$ & None reported & $\begin{array}{l}\text { Discontinued } \\
\text { dupilumab } \\
\text { and added } \\
\text { methotrexate for } \\
\text { several months } \\
\text { with return to } \\
\text { skin baseline }\end{array}$ & 5 \\
\hline
\end{tabular}

Table 2 Below is a chart summarizing novel case studies presented above

\begin{tabular}{|c|c|c|c|}
\hline $\begin{array}{l}\text { Patient } \\
\text { description }\end{array}$ & $\begin{array}{l}\text { Time treated AD } \\
\text { with dupilumab prior } \\
\text { to symptoms }\end{array}$ & Biopsy results & $\begin{array}{l}\text { Treatment choice for psoriform lesions when } \\
\text { occurred }\end{array}$ \\
\hline 47 year old male & 6 months & $\begin{array}{l}\text { punch biopsy performed at his } \\
\text { initial evaluation demonstrated } \\
\text { spongiotic dermatitis }\end{array}$ & $\begin{array}{l}\text { Dupilumab was discontinued, and he was switched to } \\
\text { ixekizumab. Rash worsened on new regiment so was } \\
\text { re-started on dupilumab with } 300 \mathrm{mg} \text { weekly. No lesion } \\
\text { reoccurred. }\end{array}$ \\
\hline 69 year old male & 5 months & subacute spongiotic dermatitis & $\begin{array}{l}\text { Treated with clobetasol solution and had significant } \\
\text { improvement. }\end{array}$ \\
\hline 32 year old male & I year & psoriasiform dermatitis & $\begin{array}{l}\text { Discontinued Dupilumab. Psoriaform rash persisted. } \\
\text { Only minor improvement in rash with phototherapy, } \\
\text { excimer laser, and topical steroids. }\end{array}$ \\
\hline 30 year old male & 6 months & subacute spongiotic dermatitis & $\begin{array}{l}\text { Discontinued dupilumab and started on secukinumab. } \\
\text { Psoriatic plaques resolved after } 2 \text { months. At this point, } \\
\text { dupulimab was restarted with secukinumab with no } \\
\text { lesion reoccurrence. }\end{array}$ \\
\hline 40 year old male & 9 months & psoriasis & $\begin{array}{l}\text { Dupilmab continued with methotrexate with minimal } \\
\text { improvement. Once discontinued this regiment, } \\
\text { switched to apremilast with resolution of psoriasis. }\end{array}$ \\
\hline
\end{tabular}

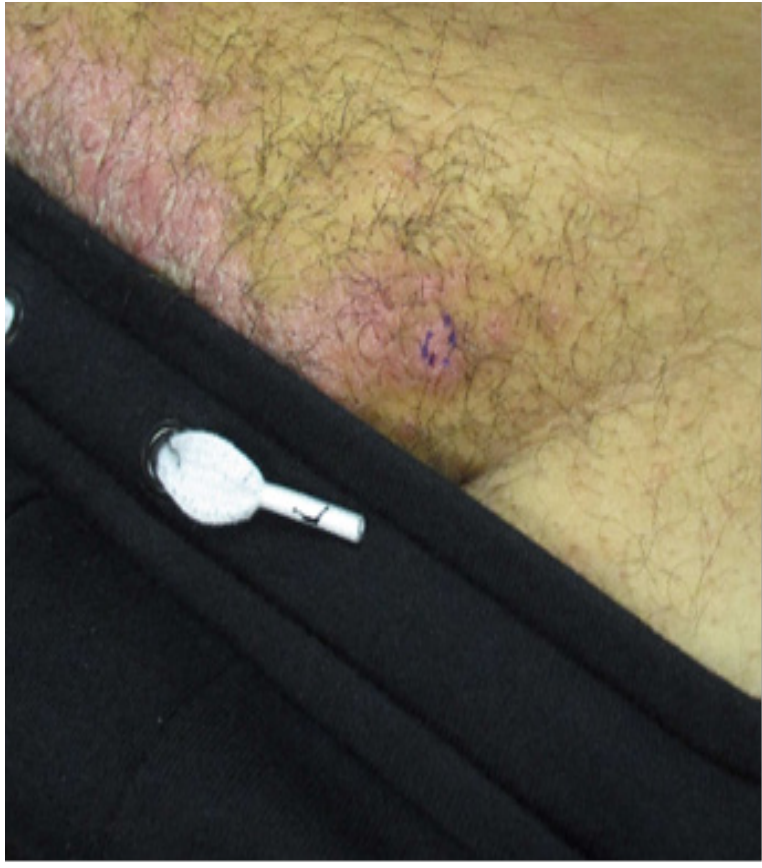

Figure I Patient 4 - Psoriasis. Psoriatic Plaques on the mons pubis, that developed after initiating dupiliumab.
Close monitoring for this side effect in patients treated with dupilumab should be alerted to dermatologists. There is reassurance in the time-limited nature of the psoriaform side-effect discussed. In the majority of cases, patients are able to fully recover after the offending agent is removed and sometimes patients are even able to restart the medication without further skin lesion development. Further studies are needed to uncover the basis for which patients are more vulnerable to this unexpected result.

\section{Conflicts of interest}

The author declares that there is no conflicts of interest.

\section{Acknowledgments}

None.

\section{Funding}

None.

\section{References}

1. Fowler E, Silverberg JI, Fox JD, et al. Yosipovitch GPsoriasiform Dermatitis After Initiation of Treatment with Dupilumab for Atopic Dermatitis. Dermatitis. 2019;30(3):234-236.

2. Gori N, Caldarola G, Pirro F, et al. A case of guttate psoriasis during treatment with dupilumab. Dermatologic Therapy. 2019;32(5). 
3. Safa G, Paumier V. Psoriasis induced by dupilumab therapy. Clinical and Experimental Dermatology. 2019;44(3):e49-e50.

4. Stout M, Guitart J, Tan T, et al. Psoriasis-like Dermatitis Developing in a Patient with Atopic Dermatitis Treated with Dupilumab. Dermatitis. 2019;30(6):376-378
5. Tracey EH, Elston C, Feasel P, et al. Erythrodermic presentation of psoriasis in a patient treated with dupilumab. JAAD Case Reports. 2018;4(7):708-710. 